Sašo Furlan

\title{
Marxova znanstvena revolucija in njena relevantnost za sodobno družboslovje
}

Ključne besede: znanstvena revolucija, kritika politične ekonomije, klasična politična ekonomija, neoklasična ekonomika, sociologija

Marx je dal Kapitalu pomenljiv podnaslov: »Kritika politične ekonomije«. Ta besedna zveza pred nas postavi nemalo težkih vprašanj. Najprej se moramo vprašati, kako naj sploh razumemo prvo besedo - »kritika«. Kaj je objekt te kritike? Katere so ključne točke, $\mathrm{v}$ katerih se kritika politične ekonomije razlikuje od same politične ekonomije? Navsezadnje se lahko vprašamo, v čem je danes aktualnost kritične intervencije $\mathrm{v}$ polje politične ekonomije. Je gesta kritike politične ekonomije, tj. znanosti, ki je v sodobnem akademskem polju že več kot sto let popolnoma pozabljena, še lahko aktualna?

\section{Klasična politična ekonomija in kritika politične ekonomije}

Kot politično ekonomijo je Marx obravnaval teoretsko produkcijo meščanskih, klasičnih ekonomistov 17., 18. in 19. stoletja, pisce vse od Williama Pettyja prek Adama Smitha do Davida Ricarda. Marx je bil v zadnjih sto dvajsetih letih tako za meščanske zgodovinarje ekonomske misli kakor za večino teoretikov socialističnih gibanj predvsem »veliki ekonomist« delavskega gibanja, Kapital pa temeljna razprava, v kateri naj bi Marx nasproti klasični politični ekonomiji postavil »marksistično politično ekonomijo«. Marx naj bi v Kapitalu prevzel in izpopolnil Smithovo in Ricardovo delovno teorijo vrednosti, katere bistvo lahko zgostimo v tezi, da je vrednost blaga določena s količino delovnega časa, potrebnega za njegovo produkcijo. Temeljni prispevek Marxove politične ekonomije pa naj bi bil v tem, da je iz delovne teorije vrednosti, ki so jo razvili klasični ekonomisti, deduciral teorijo eksploatacije delovne sile prek prilaščanja presežne vrednosti ter pokazal na neogibnost propada krizno naravnanega kapitalizma in nujnost proletarske revolucije. Implikacija tovrstnega razumevanja Kapitala je, da se ta od teorij klasikov politične ekonomije ne razlikuje v temeljnih kategorijah analize, pač pa le v svojih (političnih) posledicah.

A že sam podnaslov Kapitala meče senco dvoma na razumevanje, po katerem je bil Marxov namen napisati zgolj alternativno, malce radikalnejšo »politično ekonomijo«. 
V enem izmed pisem Ferdinandu Lassallu s konca petdesetih let je Marx omenil, da mu gre pri pisanju rokopisov (iz katerih je pozneje nastal Kapital) predvsem za kritiko temeljnih kategorij meščanske politične ekonomije, za prikaz - in hkrati radikalno kritiko - sistema buržoazne politične ekonomije (Marx, 1983). Marxov namen pri pisanju Kapitala torej ni bil ne izpopolnjevanje klasične ekonomske teorije ne zgolj kritika posameznih teorij politične ekonomije, temveč kritika osnovnih kategorij politične ekonomije. Kot poudarja Michael Heinrich, je bila Marxova kritika usmerjena $\mathrm{v}$ temeljne predpostavke celotnega korpusa vednosti klasične politične ekonomije, ki je nemalokrat vseboval tudi nasprotujoče si teorije (Heinrich, 2012a). Prav tovrstna radikalnost Marxovega pristopa je botrovala temu, da je Marx svoj projekt kritike politične ekonomije popolnoma upravičeno obravnaval kot znanstveno revolucijo.

A v čem natančno je revolucionarnost Marxovega teoretskega projekta? $\mathrm{Na}$ kakšen način njegovo delo radikalno prelamlja s predhodniki? Pri poskusu odgovora na to vprašanje se bomo oprli na Heinrichovo tezo o štirih rezih Marxove kritike politične ekonomije glede na teoretsko polje klasične politične ekonomije. Pri tem gre v bistvu za reze glede na štiri predpostavke, ki na najosnovnejši ravni določajo polje klasične politične ekonomije (Heinrich, 2012a; Heinrich, Wei, 2011). Po Heinrichu so te predpostavke antropologizem, individualizem, empiricizem in ahistoricizem.

\section{Rez glede na antropologizem}

Antropologizem, iz katerega je črpala in nad katerim se je navdihovala klasična politična ekonomija, temelji na ideji človekovega bistva, na nereflektirani ideji človekove večne in nespremenljive esence. V Smithovem Bogastvu narodov je antropologizem kar najbolje zgoščen v splošni opredelitvi človeka kot bitja, ki se po svoji naravi od živali razlikuje po nagnjenju k trgovanju, barantanju in menjavi (Smith, 2010, 21). Marx je prelomil ne le s tovrstnimi meščanskimi teorijami človekovega bistva, ki so $\mathrm{v}$ najbolj priljubljenih različicah povzdigovale nagnjenja omikane buržoazne gospode $\mathrm{v}$ družbi generalizirane blagovne menjave v človekovo transhistorično esenco, ampak z razmišljanjem v esencialističnih kategorijah nasploh. Čeprav je Marx v nekaterih zgodnjih spisih, na primer v Pariških rokopisih iz leta 1844, s svojo teorijo odtujitve sam zapadel antropologizmu, saj se je opiral na Feuerbachovo ahistorično, abstraktno in kontemplativno koncepcijo človekovega bistva, je prelom $z$ antropologizmom napovedal že v Tezah o Feuerbachu iz leta $1845 .{ }^{1} \mathrm{~V}$ 6. tezi je namreč poudaril, da »človeško bistvo ni nikak abstraktum, prebivajoč v posameznem individuu. V svoji dejanskosti je skupek [Ensemble] družbenih razmerij« (Marx, 2008, 33). V spisu Grundrisse iz leta 1857, ki

1 V leto 1845 je Marxov »epistemološki rez« glede na feuerbachovski humanizem ter teleološke in esencialistične elemente heglovskega idealizma datiral tudi Louis Althusser (2005). 
je prvi očrt Kapitala, je Marx domnevno generične atribute človeka kot neodvisnega individua, nagnjenega $\mathrm{k}$ menjavi, ki se (običajno $\mathrm{v}$ najrazličnejših robinzonadah) pojavlja v izhodišču tako Smithove kakor Ricardove teorije, razkrinkal kot produkt zgodovinskega razvoja, ki je po 16. stoletju pripeljal do postopnega razkroja fevdalnega sistema in sočasnega hitrega razvoja produkcijskih sil ter ekspanzije trgovine (Marx, 1973, 83). Šele v tem zgodovinskem kontekstu, ki je marsikaterega človeka dejansko osvobodil od neposrednih oblik dominacije in spon narave, je lahko vzniknil ideal svobodnega človeka trgovca, ki je bil nato nereflektirano projiciran v preteklost in $\mathrm{v}$ samo človekovo, od narave ali celo boga dano univerzalno bistvo.

\section{Rez glede na individualizem}

Drugi ključni prelom s teoretskim poljem politične ekonomije je rez glede na (metodološki) individualizem, ki se je v meščanski ekonomiji kazal v razumevanju družbenoekonomskih pojavov kot izrazov dejanj posameznikov. Ta so bila pri klasikih osnovno izhodišče za analizo družbenoekonomskih odnosov. Marx je k tovrstni analizi pristopil iz obratne smeri. Čeprav ljudem ni odrekal možnosti ustvarjanja njihove lastne zgodovine, ni pozabil dodati, da je ne ustvarjajo, »kakor bi se njim zljubilo, ne delajo je v okoliščinah, ki so si jih izbrali, temveč v okoliščinah, na kakršne so neposredno naleteli« (Marx, 1967, 452). V Grundrisse Marx to stališče zgosti v tezi, da družba ni iz individuov, temveč izraža vsoto odnosov, ki šele določajo mesta individuov v družbi (Marx, 1973, 265). Zato v nasprotju s klasiki Marx svoje analize ne začenja $\mathrm{z}$ analizo dejanj izoliranih posameznikov, temveč $\mathrm{z}$ analizo družbenih razmerij.

Ta odmik od individualizma je v Kapitalu očiten že pri analizi najabstraktnejše kategorije politične ekonomije - vrednosti. Čeprav sta Smith in Ricardo podobno kakor Marx obravnavala delo kot vir vrednosti, delovni čas pa kot tisto, kar določa velikost vrednosti blaga, je bila metoda, s katero sta prišla do te ugotovitve, popolno nasprotje Marxove. Zato tudi Marxova delovna teorija vrednosti ni bolj sofisticirana različica teorije vrednosti, ki so jo razvili klasiki, ampak se od nje radikalno razlikuje. Smith je na primer ugotovitev, da je vrednost določena $\mathrm{z}$ delovnim časom, izpeljal iz dejstva, da vsakršna produkcija blaga zahteva določeno mero človeškega truda, nato pa poskušal dokazati, da je prav količina truda tisto, kar posamezniki v svoji praksi barantanja in trgovanja upoštevajo kot glavno določilo (menjalne) vrednosti blaga. Čeprav se zdi, da je delovna teorija vrednosti, s katero je operirala klasična politična ekonomija, »objektivna « teorija vrednosti, saj naj bi za določilo velikosti vrednosti blaga postavila kvantitativno izmerljiv delovni čas v sferi produkcije, pa je v svojem bistvu prav zaradi svojega metodološkega individualizma subjektivistična. Kot je razvidno iz Smithove izpeljave, določitev vrednosti blaga ni izpeljana iz družbenih zakonov 
produkcije in menjave, temveč iz racionalnosti posameznika, ki pri trgovanju poskuša uskladiti vrednost blaga $s$ količino dela, ki je bilo vloženo v njegovo produkcijo. Kot poudarja Heinrich, Marx v Kapitalu v nasprotju s Smithom, ki poskuša zakone menjave deducirati iz opazovanja posameznega in izoliranega akta menjave, posamezen akt menjave obravnava kot del določene družbene totalnosti, v kateri je reprodukcija družbe posredovana z menjavo (Heinrich, 2012b, 46-47). Šele z gledišča totalnosti, ki ga zavzame Marx, je namreč mogoče izpeljati »objektivno « delovno teorijo vrednosti. ${ }^{2}$ Marx torej ni preprosto prevzel in izpopolnil delovne teorije vrednosti klasikov. Ta je bila utemeljena na precej nejasni tezi, da je vrednost blaga določena $\mathrm{z}$ delovnim časom, potrebnim za njegovo produkcijo, in šele Marx je ugotovil, da je določena $z$ družbeno potrebnim delovnim časom, ki je v Kapitalu definiran kot »delovni čas, ki je potreben za izdelavo kakršnekoli uporabne vrednosti ob danih družbeno normalnih produkcijskih pogojih in ob družbeno povprečni stopnji spretnosti in intenzivnosti dela« (Marx, 1961, 48). Vrednost samo pa je Marx s tem lahko analiziral kot družbeni odnos in ne kot smithovsko in ricardovsko substanco, utelešeno $\mathrm{v}$ posameznih blagih. Do teh ugotovitev je lahko Marx prišel le, ker je prelomil z metodološkim individualizmom in individualna dela obravnaval $\mathrm{z}$ vidika totalnosti, kot »kristale« celotnega družbenega dela.

\section{Rez glede na empiricizem}

Tretja predpostavka, ki je opredelila polje politične ekonomije, je empiricizem. V Teorijah presežne vrednosti Marx ugotavlja, da je bila empiricistična filozofija, zlasti filozofija Johna Locka, izhodišče vseh idej klasične politične ekonomije (Pilling, 1980). Bistvo empiricizma je teza, da je čutno izkustvo edini vir vednosti. Empiričnemu opazovanju dostopne ekonomske kategorije so zato klasiki imeli za primarni objekt politične ekonomije. Marxova metoda proučevanja kapitalističnega produkcijskega načina pa je bila, nasprotno, izrazito antiempiricistična. To ne pomeni, da je bila uperjena proti empiričnim analizam oziroma proti uporabi empiričnih podatkov pri analizi kapitalističnega produkcijskega načina - Kapital prinaša ogromno zgodovinskih analiz številnih ekonomskih trendov, ki so podkrepljene s skoraj nepregledno količino empiričnih podatkov. Uperjena je bila proti empiricizmu, ki se je pri klasikih kazal v metodi, ki je izhodiščni objekt znanstvene analize videla v skupku z izkustvom pridobljenih, empirično danih družbenoekonomskih »dejstev«, ki so bila brez nadaljnje refleksije nekritično sprejeta kot fiksni, naravni pojavi, na podlagi katerih je bila zgrajena analitična struktura teoretskega polja politične ekonomije.

2 Ko govorimo o »objektivnosti« Marxove teorije vrednosti, ne merimo na njeno univerzalno nadzgodovinsko veljavnost. Govorimo o objektivnosti, ki je družbeno skonstruirana in zgodovinsko specifična. 
Družbenoekonomski odnosi $\mathrm{v}$ kapitalističnem produkcijskem načinu so se zato kazali kot nekaj popolnoma prosojnega oziroma kristalno jasnega - ves material, ki je predstavljal objekt politične ekonomije, je bil neposredno dostopen čutni zavesti, za njim pa se ni skrivalo prav nič skrivnostnega.

To stališče je v svojih zgodnjih spisih zagovarjal tudi Marx. V Komunističnem manifestu je skupaj z Engelsom religiozne in politične iluzije opisoval kot stvar preteklosti, predmodernih fevdalnih odnosov, ki $\mathrm{v}$ kapitalizmu, temelječem na golem in odkritem izkoriščanju, prej ali slej izginejo (Marx, 2009, 98). A kasneje je Marx to stališče opustil - v Kapitalu je blagovni svet kapitalistične družbe opisal kot poln skrivnosti, mistifikacij in teoloških muh, o osnovni kategoriji kritike politične ekonomije, blagu, je govoril kot o »čutno-nadčutni stvari« in pri njegovi analizi je pogosto uporabljal metafore iz religioznega sveta. Tu ne gre le za Marxov ekscentrični slog pisanja, temveč za mistifikacije, ki so v jedru same realnosti kapitalističnega sveta in ki jih empiricistična analiza še zdaleč ni mogla razkriti.

Marx je osnovne družbenoekonomske odnose v kapitalizmu v nasprotju s klasiki opisal kot inherentno zaslepljujoče in neprosojne. To je storil v svoji teoriji blagovnega fetišizma. Z njo je pokazal, da so v družbi generalizirane blagovne menjave ljudje pod nadzorom »stvari« in da odločilni odnosi dominacije niso osebni, temveč »objektivni« (»sachlich«). Tovrstna neosebna, objektivna dominacija ne obstaja zato, ker bi stvari same posedovale značilnosti, ki bi generirale to dominacijo, ampak zato, ker jo generira specifična družbena praksa, $v$ kateri funkcijo posredovanja te aktivnosti privzamejo stvari, in sicer specifične stvari - blaga. Objektivna dominacija in objektivacija družbenih odnosov, ki se kažejo kot lastnosti stvari, sta rezultata specifičnih družbenih praks blagovne družbe in nista neposredno dostopni vsakdanji čutni zavesti (Heinrich, 2012b, 75). Za to spontano zavest imajo »oblike, ki dajejo produktom dela pečat blaga [...], trdnost naravnih oblik družbenega življenja « (Marx, 1961, 88). Zato se zdi, kot da so nespremenljive in kot da nimajo zgodovinskega značaja.

Spontana zavest se v tem primeru ne razlikuje od zavesti političnih ekonomistov, saj je bila tudi ta zaslepljena $\mathrm{z}$ iluzijami. Te iluzije, kot poudarja Marx, niso plod subjektivne zaslepljenosti posameznih ekonomistov, temveč objektivne iluzije, ki izhajajo iz teh oblik samih: »Kategorije meščanske ekonomije [...] sestoje iz takšnih oblik. To so družbeno veljavne, torej objektivne miselne oblike za produkcijske odnose tega zgodovinsko določenega družbenega načina produkcije, produkcije blaga« (Marx, 1961, 89). Prav te »objektivne miselne oblike« določajo tisto, kar so meščanski ekonomisti privzeli kot neposredno danost, kot »očiten« objekt politične ekonomije. Pri klasikih tako manjka vsakršna refleksija specifičnosti družbenih oblik, ki so določale kategorije njihove analize, saj so se ukvarjali zgolj z njihovo vsebino; 
kot pravi Marx: „Četudi nepopolno, je politična ekonomija analizirala vrednost in velikost vrednosti, ter je odkrila vsebino, ki je skrita v teh oblikah. Nikdar pa se ni niti vprašala, zakaj dobiva ta vsebina takšno obliko, zakaj se torej delo kaže v vrednosti in zakaj se mera dela s svojim časovnim trajanjem kaže v velikosti vrednosti delovnega produkta« (Marx, 1961, 93-94). Prav z analizo specifičnih družbenih oblik kategorij politične ekonomije in s teorijo blagovnega fetišizma, ki pokaže, zakaj te oblike porajajo objektivne iluzije, zaradi katerih so za spontano zavest zastrte, se Marx odtegne empiricizmu klasikov.

\section{Rez glede na ahistoricizem}

Četrti prelom Marxove kritike politične ekonomije s klasično politično ekonomijo je rez glede na ahistoricizem. Klasični ekonomisti so, kot poudarja Marx, ravnali na poseben način: "Zanje sta le dve vrsti ustanov, umetne in naravne. Ustanove fevdalizma so umetne, buržoazije pa naravne. V tem so enaki teologom, ki prav tako postavljajo dve vrsti ver. Tista vera, ki ni njihova, je človeška iznajdba, njihova lastna pa je božje razodetje. - Tako je torej zgodovina bila, je pa ni več« (Marx, 1961, 95). Klasična ekonomija je na podlagi dejstva, da mora vsaka družba za svoje preživetje nekaj producirati in produkte nekako porazdeliti, ekonomske probleme obravnavala kot probleme, ki se v enaki obliki pojavljajo v vseh zgodovinskih obdobjih. Zaradi transhistoričnega pristopa do ekonomskih problemov so klasični ekonomisti pri analizi vselej uporabljali enake kategorije (Heinrich, Wei, 2011). V nasprotju z njimi je Marx kapitalizem prepoznal kot historično specifičen produkcijski način, ki se radikalno razlikuje od antične sužnjelastniške družbe ali srednjeveškega fevdalizma. Vsak od teh specifičnih produkcijskih načinov po Marxu je ves v zgodovinsko specifičnih družbenih odnosih, ki jih ne moremo razdeliti na umetne in naravne in ki jih moramo tudi analizirati s specifičnimi kategorijami, katerih veljavnost je omejena na specifično zgodovinsko dobo. Medtem ko so temeljne kategorije politične ekonomije zaradi odsotnosti teorije zgodovinskih produkcijskih načinov pri klasikih privzele podobo transhistoričnih pojmov, so temeljne kategorije kritike politične ekonomije, čeprav so pogosto poimenovane $\mathrm{z}$ enakimi imeni, v svojem temelju historične.

\section{Marxovi rezi kot teoretske intervencije v polje sodobne neoklasične ekonomike in buržoazne sociologije}

Marxovo znanstveno revolucijo smo opisali kot niz štirih rezov glede na polje klasične politične ekonomije. Če jo interpretiramo kot niz posegov v teoretsko polje politične ekonomije, ki je bila že v poznem 19. stoletju nadomeščena $\mathrm{z}$ neoklasično ekonomiko, proučevanje marsikaterih družbenih pojavov, ki so včasih spadali $\mathrm{v}$ 
njeno polje, pa je prevzela buržoazna sociologija, je aktualnost Marxove intervencije postavljena pod vprašaj. Kot poudarja Immanuel Wallerstein, se je v poznem 19. stoletju $\mathrm{v}$ meščanskem svetu uveljavila in institucionalizirala delitev družboslovnih disciplin, ki je bila tako klasikom kakor Marxu nepoznana. Zajemala je tako delitev med družbenimi vedami in zgodovino kakor notranjo delitev polja znanosti o družbi na sociologijo, ekonomijo in politično znanost. Sama razmejitev ekonomije, sociologije in politične znanosti je bila posledica globalnega zmagoslavja buržoazne ideologije, po kateri se družba deli na tri avtonomne sfere: na trg, s katerim se ukvarja ekonomija; državo, s katero se ukvarja politična znanost; in civilno družbo, s katero se ukvarja sociologija (Wallerstein, 1999).

Je lahko v kontekstu te razdelitve disciplin, ki v akademskem polju vlada še danes, Marxova znanstvena revolucija sploh še aktualna? Lahko Marxovo kritiko politične ekonomije uporabimo tudi kot intervencijo v polje sodobne neoklasične ekonomike in sodobne meščanske sociologije? Če bi bila Marxova kritika politične ekonomije kritika posameznih teorij politične ekonomije, bi moral biti odgovor negativen. A ker je bila, kot smo poudarili, v temelju kritika samih predpostavk politične ekonomije, lahko odgovorimo pritrdilno. Tako polje sodobne neoklasične ekonomike kakor polje sodobne buržoazne sociologije ${ }^{3}$ določajo prav tiste predpostavke, ki so določale klasično politično ekonomijo. Obe polji sta namreč v precejšnji meri kontaminirani $\mathrm{z}$ antropologizmom, individualizmom, empiricizmom in ahistoricizmom.

O neoklasični ekonomiki lahko rečemo, da jo v celoti določajo vse štiri navedene predpostavke. Marginalistična ekonomska teorija, ki je jedro neoklasične ekonomike, je utemeljena na antropologizmu, natančneje, na ideji večnega in univerzalnega bistva človeka kot homo economicus, ki je po svoji naravi nagnjen $\mathrm{k}$ maksimizaciji individualne koristi. S klasično politično ekonomijo jo druži tudi empiricizem. Neoklasična ekonomika namreč operira izključno z empiričnimi kategorijami, kakršne so cene, plače in profiti. Material njene analize je reduciran na empiričnemu opazovanju dostopne in kvantitativno izmerljive spremenljivke. Marginalistična teorija vrednosti je subjektivistična teorija, utemeljena na (metodološkem) individualizmu. $\mathrm{V}$ izhodišče analize vrednosti ne postavlja družbenih odnosov, pač pa izoliran odnos med posameznikom in stvarjo, zato vrednosti ne pojmuje kot družbeni odnos, ampak kot nekaj, kar naj bi bilo določeno s preferencami individuov (Mandel, 1962). Prav tako je neoklasična ekonomika zaznamovana $\mathrm{z}$ ahistoricizmom. Historična specifičnost kapitalističnega produkcijskega načina je v njej odmišljena, saj so ekonomski problemi, ki si jih zastavlja, opredeljeni kot problemi, ki se pojavljajo v vseh zgodovinskih obdobjih - ne glede na zgodovinski kontekst je ekonomija razumljena kot veda »o alokaciji redkih resursov«, kot veda, ki z večno veljavnimi kategorijami ponuja rešitve za večne ekonomske probleme.

3 Za natančnejšo obravnavo sistema sodobnega družboslovja gl. Močnik (2009). 
S temi predpostavkami je v marsičem določeno tudi polje sodobne buržoazne sociologije. Za dobršen del sociologije preteklega in tega stoletja je značilna pozitivistična paradigma, utemeljevanja katere se je že v prvi polovici 19. stoletja loteval Auguste Comte, a se je kot prevladujoča paradigma sociologije zlasti na Zahodu uveljavila šele po drugi svetovni vojni. ${ }^{4}$ Comtov pozitivizem, ugotavlja še Boris Ziherl, ostaja najustreznejša podlaga buržoaznega liberalizma moderne sociologije (Ziherl, 1960). Pozitivistična sociologija se pri analizi družbenih pojavov omejuje na raziskovanje empiričnih pojavov, ki jih je mogoče kvantificirati in medsebojno primerjati. Vsakršna analiza družbenih zakonov, tendenc, ki determinirajo te empirične pojave, je iz empiricističnega okvira buržoazne sociologije izključena. Prav tako je izključena zgodovina, saj je sleherna družbena sprememba lahko dojeta zgolj kot kvantitativni razvoj družbenih odnosov v okviru predpostavljenega obstoječega reda, ne pa kot zgodovinska preobrazba v obliki kvalitativnih skokov (Ziherl, 1960). Družba je pri tem reducirana na vsoto individuov, ki so s svojimi hotenji in voljo izhodišče za analizo družbenih odnosov. To pomeni, da je v svojih osnovnih določitvah sodobna sociologija zaznamovana tudi $\mathrm{z}$ individualizmom. Ta pa je $\mathrm{v}$ večini primerov dopolnjen $\mathrm{z}$ antropologističnim esencializmom, ki zgodovinsko specifične značilnosti individuov, določene $\mathrm{z}$ družbenimi odnosi, $\mathrm{v}$ katere so ti individui vpeti, projicira $\mathrm{v}$ njihovo od narave dano bistvo.

Marxova znanstvena revolucija se je pojavila kot kritika osnovnih predpostavk politične ekonomije. Politično ekonomijo pa $\mathrm{v}$ temelju določajo predpostavke, ki določajo tudi buržoazne družboslovne znanosti. Prav zato je Marxova kritika teoretsko orožje, s katerim lahko interveniramo ne le v klasično politično ekonomijo, temveč tudi v polje neoklasične politične ekonomike in sodobne meščanske sociologije.

\section{Literatura}

Althusser, L., For Marx, London 2005.

Smith, A., Bogastvo narodov, Ljubljana 2010.

Heinrich, M., The Developement of Marx's Theory of Value, and its Ambivalences, Communism, 2012a, http://communism.blogsport.eu/2012/08/24/michael-heinrichthe-development-of-marxs-theory-of-value-and-its-ambivalences-english $\quad\left[\begin{array}{ll}17 . & 3 .\end{array}\right.$ 2013].

Heinrich, M., An Introduction to The Three Volumes of Karl Marx's Capital, New York 2012b.

4 Druga smer, v katero tokovi zlasti po sedemdesetih letih 20. stoletja vlečejo drugi del buržoazne sociologije, pa je utemeljena na postmodernistični paradigmi, ki se opira na kulturni relativizem, $\mathrm{v}$ svojih metodah pa je večinoma eklektična. 
Heinrich, M., Wei X., The Interpretation od Capital: An Interview with Michael Heinrich, World Review of Political Economy 2, št. 4, 2011, http://www.cssn.cn/ upload/2013/02/d20130220095249180.pdf [17. 3. 2013].

Mandel, E., Marxist Economic Theory, New York 1962.

Marx, K., Kapital I, Ljubljana 1961.

Marx, K., »Osemnajsti brumaire Ludvika Bonaparta«, v: Marx, K., Engels, F., Izbrana dela III, Ljubljana 1967, str. 445-574.

Marx, K., Grundrisse, London 1973.

Marx, K., Marx to Ferdinand Lassale in Düsseldorf, v: Marx, K., Engels, F., Collected Works, vol. 40, Moskva 1983, str. 268.

Marx, K., Marx o Feuerbachu, v: Marx, K. in drugi, O spremembi sveta, Ljubljana 2008.

Marx, K., Engels F., Komunistični manifest, Ljubljana 2009.

Močnik, R., Spisi iz humanistike, Ljubljana 2009.

Pilling, G., Marx's Capital, Philosophy and Political Economy, London 1980.

Ziherl, B., Historični materializem in sociologija, v: Ziherl, B., Včeraj in danes, Ljubljana 1974, str. 147-170.

Wallerstein, I., Utopistike ali Izbira zgodovinskih možnosti 21. stoletja; Dediščina sociologije: obljuba družbenih ved, Ljubljana 1999. 
Sašo Furlan

\section{Marx's scientific revolution and its relevance for contemporary social science}

Keywords: scientific revolution, the critique of political economy, classical political economy, neoclassical economics, sociology

Marx's scientific revolution is not an intervention into a certain specific theory of political economy, but an intervention in the form of critique of fundamental presuppositions of political economy in general. Hence, the theoretical apparatus of the critique of political economy can also be used as a tool for intervening into the field of contemporary social sciences, particularly into neoclassical political economy and modern bourgeois sociology, insofar as they are based precisely on the presuppositions that are the object of Marx's critique. Following Michael Heinrich's interpretation of Marx's critical theory, the article argues that Marx's critique of political economy consists of four fundamental breaks with the theoretical field of classical political economy, that is, with the latter's anthropologism, individualism, empiricism and ahistoricism. This critique is primarily directed not toward individual theories of political economy, but toward the presuppositions shared by all theories of political economy. 